\title{
若手健康心理学者からみる健康心理学における 社会連携の可能性
}

第 6 回ヤングヘルスサイコロジストの会シンポジウム

$\begin{array}{ll}\text { 企画者 } & \text { ヤングヘルスサイコロジストの会 } \\ \text { 司会者 } & \text { 中村美幸（順天堂大学大学院） } \\ \text { 話題提供者 } & \text { 松田晃二郎（九州栄養福祉大学） } \\ \text { 話題提供者 } & \text { 三原健吾（久留米大学） } \\ \text { 話題提供者 } & \text { 堀本菜美（順天堂大学大学院） } \\ \text { 話題提供者 } & \text { 樋田琴乃（大妻女子大学大学院） } \\ \text { 指定討論者 } & \text { 森下久美（桜美林大学大学院） }\end{array}$

\section{企画趣旨}

本シンポジウムのテーマは「若手健康心理学者からみる健 康心理学における社会連携の可能性」である。

学問の社会連携の形態は，大学等の研究機関と民間企業に おける共同研究・受託研究事業といった研究活動や, 教育プ ログラムの開発といった教育面での連携など多様である。ま たその意義は, 社会的課題の実態把握・解決や, 研究者側の 新たな目的意識，独創的コンセプトの獲得に貢献する（文部 科学省, 2003)。

しかし近年，研究成果の社会還元が停滞傾向にあることが 指摘されている（文部科学省，2018）。その背景には，研究機 関と企業や地域組織との繋がりが弱いこと, 社会的課題への 目的意識やアプローチが不的確であること，得られた知見や 開発したシステムの普及戦略が不十分であることなどがある。

健康心理学では，健康への多種多様なアプローチの構築を 目指寸上で，この課題とどのように向き合うべきだろうか。 どのように社会との繋がりをもち, 研究成果を還元し, さら に実践活動においてそれを深めることができるのか。これか らの社会に向け，考え，そして実践することが重要である。

第 6 回目となる本シンポジウムでは，健康心理学という応 用学問が持つ社会連携の可能性について, 若手健康心理学者 が取り組む研究や実践活動を通じて, 多くの研究者, 臨床家, 実践家と社会連携の可能性を広げていきたい。

\section{話題提供者 松田晃二郎（九州栄養福祉大学）}

話題内容「スポーツ選手におけるイップスの経験と心理的 変容」

イップスとは，元来，ゴルフのパッティング時に認められ る筋緊張や筋硬直などを指寸用語であったが，近年では，野 球やクリケット等の種々のスポーツ種目で類似の運動障害が 確認されている (Papineau, 2015)。また，イップスの症状は， 長期的に現れ，最悪の場合，スポーツ選手を引退にまで追い 込む可能性が指摘されている (Philippen et al., 2012)。このよ うなスポーツ選手に及ぼす影響力の多大さゆえに，イップス 研究者はこれまで，イップスの経験がスポーツ選手に及ぼす
否定的な影響の理解とその対処法の検討に尽力してきた (Bell et al, 2011)。しかしながら，私は，先行研究の考証を進 める中で,「イップスの経験は必ずしも全てのスポーツ選手に とって否定的な影響をもたらすのだろうか」といった疑問を 持つようになった。このような疑問に端を発し，私の研究で は，イップスの経験に伴った否定的な心理的変化だけではな く, 肯定的な心理的変化に着目し, 研究を進めている。実際, スポーツ場面における種々のストレスフルな経験 (スポーツ 傷害など) は，スポーツ選手が肯定的な心理的変化を遂げる 契機になりうるという報告が散見される（中村ら，2018; Tamminen et al., 2013)。

このようなストレスフルな経験に伴った肯定的な変化の実 態を明らかにしていくことは，ストレスフルな経験に苦しむ スポーツ選手に対するサポートを行う上での有益な情報提供 を可能にする。また，スポーツ場面における多様なストレス フルな経験に伴った肯定的な変化は, 日常生活での困難な出 来事に対する考え方や対処の様を肯定的に変化させる可能性 も否定できない。

本シンポジウムでは，以上のような点を踏まえ，健康心理 学の視点から最新の研究知見および今後の展望に関して論じ たい。

\section{話題提供者 三原健吾（久留米大学）}

話題内容「well-being が生物心理学的ストレス反応に与え る影響」

近年, 健康-病気の結果を左右するポジティブな心理的要因 として well-being が注目されている。well-being はストレスや 抑うつ気分，身体疾患の緩和など現在の心身の健康状態ばか りでなく, 将来の心血管疾患発症の予防や寿命の長さなど適 応的役割を有する。その well-being と健康-病気の結果の背後 には神経系, 内分泌系, 免疫系といった生理的機能が密接に 関与している。それゆえ, well-being の生物心理的基礎過程 を明らかにすることは, 疾病の予防や積極的な健康づくりに おいて極めて重要である。また, 欧米では, 基礎研究に加え, well-being に積極的に働きかけた健康開発的な介入実践も進 
められている。例えば, 習慣的に感謝の気持ちを記すことで, 主観的な睡眠の質と拡張期血圧が改善することが明らかにさ れている (Jackowska et al., 2015)。これらの研究は，社会に 貢献できる基礎と臨床の橋渡し研究としての役割を担うと考 えられる。

我々の研究では，理論的，実証的に区別される 2 タイプの well-being，すなわち hedonic well-being（ポジティブ感情や人 生満足感などの快楽的側面）と eudaimonic well-being（人生の 目的や自己成長感などの実存的側面）が唾液中コルチゾール や s-IgA などの心理生物学的反応とどのように関連するのか 日常生活場面及び実験室場面で調べた。その結果, eudaimonic well-being は，コルチゾール，ノルアドレナリンの低さと関 連することや，急性ストレス負荷後のノルアドレナリン神経 系及び副交感神経活動の回復の早さに影響を与えることが明 らかとなった。

本シンポジウムでは，ストレス過程における well-being の 生物心理的機能について, 我々の研究や最新の研究知見を紹 介しながら, 今後の健康心理学研究や社会連携の在り方につ いて論じたい。

\section{話題提供者 堀本菜美（順天堂大学大学院）}

話題内容「青年期の運動部活動におけるハラスメント問題 の解決に向けて : 認知尺度の開発による今後の発展」

近年，運動部活動における指導者からの暴力や暴言などの 立場を利用した嫌がらせが問題視されている。暴力などの体 罰においては，高校生の自殺などにより，スポーツ指導の場 で長年体罰が容認，放任されてきたことに厳しい目が注がれ るようになった（西山，2014）。体罰は法律で禁じられた行為 であり, 文部科学省も実態調査等を行なっている。実態調査 より，2012 年度に 6721 件だった体罰件数が，2017 年度には 773 件に減少しているが，根絶に至っていない。また，文部 科学省（2013）は「運動部活動での指導のガイドライン」に おいて体罰等の許されない指導の例を挙げており，パワーハ ラスメントと判断される言葉や態度による务し, 威圧・威嘘 的発言や行為,嫌がらせ等を行うというものも明記している。 これらの問題から，体罰問題に関する研究が取り上げられて おり，体罰行為の実態把握や体罰への認識調査が行われてい るが，具体的に選手がどのような行為をパワーハラスメント と認識しているのかは明らかになっていない。

これらの問題点の解決策として，暴力行為以外の指導者か らの嫌がらせを明らかにし，現在不明瞭である運動部活動に おけるパワーハラスメントの環境要因や，選手個人の要因と の関連を検討する際にも有力な指標となる尺度の開発が急務 であると考えられる。尺度を用い，青年期の運動部活動にお ける指導者からのパワーハラスメントについての実態を把握 することができれば，パワーハラスメントと認知される行為 について，指導現場へ具体的に明示寸ることができると考え られる。

本シンポジウムでは，尺度作成時の調査で明らかとなった 運動部活動におけるパワーハラスメントの実態を踏まえ，健
康心理学の観点から教育現場や運動部活動に関わる行政への アプローチ方法や今後の運動部活動指導の課題などについて 論じる。

\section{話題提供者 樋田琴乃（大妻女子大学大学院）}

話題内容「月経随伴症状に対する連携支援の現状と課題」 月経とは，「周期的に繰り返され，かつ限られた日数で自然 に終わる子宮からの出血」と定義され（松本，2004），女性の 健康のバロメーターとなるなど, 重要な役割を果たす一方で, 下腹部痛・腰痛をはじめ, 頭痛, 吐き気, 憂うつ, 情緒不安 定感などの随伴症状があり（日本産婦人科学会・日本産婦人 科医会, 2011)，こうした月経随伴症状は身体的精神的ストレ ッサーとなり，抑うつなどの精神的健康に影響を及ぼすこと が報告されている（服部ら，1998）。21,477人の女性を対象に 実施された大規模な調査によると, 月経随伴症状による労働 損失を合計すると，社会経済的な損失は年間 6,828 億円にも のぼると想定されている（Tanaka et al，2013）。このことか ら, 月経随伴症状の影響は女性だけでなく, 社会全体の重大 な問題であり, 月経随伴症状の適切で有効な治療, 対処につ いて検討することは急務であるといえる。

月経随伴症状に対する主な治療法として，非ステロイド性 抗炎症剂（NSAIDs）が広く有効とされる他，鎮痤剂や経口避 妊薬（低用量ピル）などの薬物療法が幅広く使われているが (相良, 2009)，一方で薬物の副作用に不安を抱く人が多いこ とも指摘されている（服部ら，2001）。以上から，月経随伴症 状の治療及び対処として, 薬物療法が有効とされる半面, 副 作用やコストなど問題点も挙げられ，月経随伴症状と心理的 状態との関連性ついて指摘されていることからも（松本，20 04），薬物療法と併せた心理的介入が必要である。

しかしながら, 月経随伴症状に関する介入研究の多くは, 医学的・看護学的見地に基づく研究が多く, 月経随伴症状を 心理学的知見から捉えた研究は数少ないのが現状である。こ うした専門間での知見の差異は, 多職種連携が求められる中, 葛藤を生む要因となることも考えられるため，共通の包括的 な支援アプローチシステムが重要となるであろう。

本シンポジウムでは，月経随伴症状を抱える女子学生の心 理学的特性・状態を示した上で，多職種連携の視点から，月 経随伴症状に対する支援の課題や展望について論じたい。

利益相反開示：本シンポジウムにおける発表に関連し，開 示すべき利益相反関係にある企業などはありません。

謝辞

本シンポジウムの実施に際して，ご尽力いただきました， 大会準備委員長の津田彰先生 (久留米大学) をはじめ, 準備 委員の先生方，世話人の喜屋武享先生（沖縄女子短期大学）, 山口慎史先生 (順天堂大学 PD) に心より御礼申し上げます。

(NAKAMURA Miyuki, HORIMOTO Nami, MTSUDA Kojirou, MIHARA Kengo, TOYUDA Kotono, MORISHITA Kumi) 